\title{
PENGARUH MODEL PEMBELAJARAN NUMBER HEAD TOGETHER (NHT) TERHADAP HASIL BELAJAR PADA PEMBELAJARAN TEMATIK
}

\author{
Ika Restikawati ${ }^{1}$, Agus Budi Santosa ${ }^{2}$, Nanda William ${ }^{3}$ \\ STKIP PGRI Trenggalek \\ Email: 'restikawatiika@gmail.com, ²agus.budiku@gmai.com, ${ }^{3}$ williamnanda1@gmail.com
}

\begin{abstract}
Abstrak
Penelitian ini bertujuan untuk mengetahui pengaruh model pembelajaran Number Head Together (NHT) terhadap hasil belajar pada pembelajaran tematik. Metode yang digunakan dalam penelitian ini adalah kuantitatif dengan jenis penelitian eksperimen. Populasinya adalah seluruh siswa kelas IVA dan IVB yang berjumlah 44 siswa. Sampel yang diambil dalam penelitian ini yaitu kelas IV-B yang berjumlah 23 peserta didik. Metode pengumpulan data yang digunakan berupa tes. Tes digunakan berupa pretest dan posttest yang berjumlah 30 item.

Berdasarkan analisis data diperoleh dari nilai rata-rata hasil pretest sebesar 63,739 sedangkan nilai rata-rata hasil posttest sebesar 79,086. Artinya terdapat peningkatan terhadap hasil belajar siswa setelah diberi perlakuan dengan penerapan model pembelajaran Number Head Together (NHT) sebesar 15,347. Untuk pengujian hipotesis diperoleh sig. (2-tailed) $0,000 \leq 0,05$, maka $\mathrm{H}_{\mathrm{a}}$ diterima dan $\mathrm{H}_{0}$ ditolak. Dengan demikian, dapat disimpulkan bahwa terdapat pengaruh model pembelajaran Numbered Head Together (NHT) terhadap hasil belajar pada pembelajaran tematik.
\end{abstract}

Kata Kunci : Number Head Together, Hasil Belajar

\begin{abstract}
This study aims to determine the effect of the Number Head Together (NHT) learning model on learning outcomes in the thematic learning. The method used in this research is quantitative with ekperimental research types. The population is all students of IVA and IVB, totaling 44 students. The sample taken in this study is class IV-B, amounting to 23 students. Data collection methods used in the form of tests. The test is used in the form of pretest and posttest which amounts to 30 items.

Based on data analysis obtained from the average value of the results of the pretest of 63739 while the average value of the results of the posttest of 79,086. this means that there is an increase in student learning outcomes after being treated with the application of the learning model Number Head Together (NHT) of 15,347. For testing the hypothesis obtained sig. (2-tailed) $0,000<0,05$, then $\mathrm{H}_{a}$ is accepted and $H_{0}$ is rejected. Thus, the results of this study can be concluded that there is an influence of the Numbered Head Together (NHT) learning model on learning outcomes in the thematic learning
\end{abstract}

Keywords: Number Head Together, Learning Outcomes.

\section{Pendahuluan}

Pendidikan di era globalisasi ini dengan adanya kemajuan ilmu pengetahuan dan teknologi berkembang sangat pesat. Pendidikan adalah suatu hal yang sangat penting bagi kebutuhan setiap orang karena dengan adanya pendidikan setiap individu dapat memperoleh berbagai pengetahuan, pengalaman dan keterampilan. Pendidikan memerlukan adanya suatu proses sadar dan terencana upaya

81 | Pengaruh Model Pembelajaran Number Head Together (NHT). 
mewujudkan cita-cita dan tujuan yang diharapkannya dari setiap individu peserta didik. Namun dengan demikian, berbagai indikator mutu pendidikan dan masih belum menunjukkan adanya peningkatan yang merata dalam proses pembelajaran.

Berhasil atau tidaknya pencapaian tujuan pembelajaran tergantung dalam proses pembelajaran yang dilaksanakan oleh guru. Hal ini sejalan dengan pendapat Dick and Carey (dalam Fujiawati, 2016:21) menyatakan bahwa pembelajaran merupakan suatu proses pembelajaran dimana di dalamnya terdapat komponen-komponen yang sangat penting untuk keberhasilan belajar mengajar seperti pendidik, peserta didik dan lingkungan belajar. Namun, salah satu permasalahannya adalah rendahnya mutu pendidikan, khususnya pendidikan di Sekolah Dasar. Berbagai usaha telah dilaksanakan untuk meningkatkan mutu diantaranya melalui berbagai pelatihan dan peningkatan kualifikasi guru, penyempurnaan kurikulum, pengadaan buku dan alat pembelajaran. Pembelajaran yang sempurna hendaknya dapat membuat peserta didik ikut aktif dalam kegiatan belajar mengajar serta diharapkan akan dapat meningkatkan hasil belajar.
Hasil belajar adalah patokan yang utama untuk mengetahui tingkat keberhasilan belajar peserta didik, baik dalam perubahan tingkah laku maupun kemampuan dalam kegiatan pembelajaran. Menurut Sani (2016:120) menyatakan bahwa hasil belajar merupakan perubahan perilaku peserta didik yang didapat setelah kegiatan proses belajar. Hal senada juga diutarakan Thobroni dan Mustofa (dalam Santosa dkk, 2016:151) menyatakan bahwa hasil belajar adalah sebagai perubahan perilaku secara keseluruhan bukan hanya salah satu aspek potensi kemanusian saja. Khususnya pada pembelajaran tematik dalam proses pembelajarannya guru mengintregasikan beberapa materi pelajaran kedalam sebuah tema.

Pembelajaran tematik lebih mengutamakan pembelajaran yang berpusat pada siswa. Salah satunya dengan menggunakan model pembelajaran Number Head Together (NHT) agar siswa dapat tertarik dan menjadi lebih aktif dalam kegiatan proses pembelajaran. Hal senada diutarakan oleh Bern dan Erickson sebagaimana dikutip oleh Komalsari (dalam Jayanti dkk, 2014:04) mengemukakan bahwa pembelajaran 
kooperatif merupakan pembelajaran yang mngorganisir pembelajaran dengan menggunakan kelompok belajar kecil dimana siswa bekerja secara bersama untuk mencapai tujuan pembelajaran. Hal senada dengan pendapat Trianto (dalam Yanti, 2016:03) menyatakan bahwa model pembelajaran Numbered Head Together atau penomoran berpikir bersama merupakan model pembelajaran yang dipersiapkan oleh pendidik untuk mempengaruhi pola interaksi peserta didik dalam kegiatan berdiskusi saat proses pembelajaran berlangsung.

Berdasarkan hasil observasi yang telah dilakukan pada guru kelas IV menemukan ada beberapa permasalahan di dalam proses pembelajaran, diantaranya guru dominan menggunakan metode ceramah berpusat pada guru (teacher centered) dimana siswa kurang terlihat aktif dalam kegiatan pembelajaran. Sehingga siswa sulit untuk memahami materi yang disampaikan oleh guru karena masih dominan menggunakan metode ceramah. Menurut Suandewi dan Wibawa (2017:60) terdapat masalah yang senada yaitu berdasarkan pengalaman mengajar di kelas IV SD No. 3 Kapal dalam proses pembelajaran
IPA permasalahan yang sering muncul di kelas antara lain masih menggunakan model pembelajaran konvensional hal ini dapat mengakibatkan siswa menjadi pasif, dalam mengajar hanya menggunakan satu sumber belajar, sulit melibatkan siswa secara aktif dalam proses pembelajaran. Selanjutnya menurut Jayanti dkk (2016:02) terdapat juga masalah yaitu beberapa guru IPA, diperoleh informasi bahwa terdapat beberapa permasalahan yang diidentifikasi sebagai penyebab rendahnya hasil belajar. Pertama, pembelajaran masih berpusat pada guru. Hal ini dikarenakan guru dalam proses pembelajaran masih cenderung menggunakan model yang bersifat konvensional dari pada model pembelajaran yang dapat mengaktifkan siswa dalam proses pembelajaran. Padahal dalam kegiatan pembelajaran yang baik, aktivitas pembelajaran harus lebih banyak berpusat pada siswa. Kedua, kurangnya keaktifan siswa dalam belajar. Dalam proses pembelajaran di kelas hanya beberapa siswa yang aktif mengikuti pembelajaran, siswa lainnya hanya duduk di kelas, mendengarkan, mencatat, sehingga pada saat di berikan pertanyaan oleh guru hanya beberapa siswa yang mampu menjawab.

83 | Pengaruh Model Pembelajaran Number Head Together (NHT) 
Untuk itu perlu dilakukan kajian penelitian dengan judul "Pengaruh Model Pembelajaran Number Head Together (NHT) Terhadap Hasil Belajar Pada Pembelajaran Tematik". Adapun rumusan masalah dalam penelitian ini, yaitu apakah terdapat pengaruh model pembelajaran Number Head Together (NHT) terhadap hasil belajar pada pembelajaran tematik. Metode yang digunakan dalam penelitian ini adalah penelitian kuantitatif.

\section{Metode}

Jenis penelitian yang digunakan adalah Kuantitatif. Sifat penelitian yang digunakan adalah eksperimen. Menurut Arikunto (2013:19) menyatakan bahwa metode penelitian eksperimen adalah suatu metode penelitian percobaan yang dimaksudkan untuk mengetahui akibat atau dampak suatu kejadian atau variabel yang dihadirkan oleh peneliti. Dalam penelitian ini menggunakan PreExperimental Design. Adapun bentuk dari desain ini yaitu Pre-Eksperimental One-Group Pretest-Posttest Design. Pada desain ini terdapat pretest $\left(\mathrm{O}_{1}\right)$, diberi treatment $(\mathrm{X})$, dan diberi posttest $\left(\mathrm{O}_{2}\right)$ sehingga hasil perlakuan dapat diketahui lebih akurat, karena dapat membandingkan dengan keadaan sebelum diberi perlakuan dan sesudah diberi perlakuan. Penelitian ini dilakukan di SDN 1 Ngulankulon pada siswa kelas IV-B yang berjumlah 23 siswa dalam menerapkan model pembelajaran Number Head Together (NHT). Adapun bentuk One-Group Pretest-Posttest Design sebagai berikut.

Bagan 1. One-Group Pretest-Posttest Design

\section{$\mathrm{O}_{1} \times \mathrm{O}_{2}$}

Sumber: Sugiyono (2018: 115)

Keterangan :

$\mathrm{O}_{1}$ : Nilai pretest (sebelum diberi perlakuan)

$\mathrm{O}_{2}$ : Nilai posttest (setelah diberi perlakuan)

X : Perlakuan model pembelajaran Number Head Together (NHT)

Adapun prosedur dalam penelitian ini terdiri dari tiga tahap yaitu tahap persiapan, tahap pelaksanaan, tahap pelaporan. Tahap persiapan meliputi meminta izin untuk melakukan penelitian, menyerahkan surat izin untuk melaksanakan penelitian, konsultasi dengan pihak sekolah dan guru kelas mengenai waktu penelitian yang akan dilakukan, menentukan populasi dan sampel, menentukan tema dan subtema, membuat instrumen, konsultasi kepada dosen pembimbing, melaksanakan uji

84 | Autentik: Jurnal Pengembangan Pendidikan Dasar, Vol. 4, No. 2, Tahun 2020 
coba instrumen, menganalisis hasil uji coba instrumen, menyusun perangkat pembelajaran. Tahap pelaksanaan pada tahap ini terdapat beberapa langkah untuk melaksanakan penelitian yaitu melakukan penelitian, memberikan pretest, melakukan pembelajaran selama 6 kali pertemuan dengan cara menerapkan model pembelajaran Number Head together (NHT), memberikan posttest. Sedangkan pada tahap pelaporan yang meliputi mengolah dan menganalisis data yang sudah diperoleh berupa pretest dan posttest, menarik kesimpulan berdasarkan data yang telah diolah, melaporkan hasil penelitian.

Metode pengumpulan data yang digunakan pada penelitian ini adalah tes. Bentuk instrumen tes yang digunakan dalam penelitian ini adalah tes objektif berbentuk pilihan ganda yang berjumlah 30 item. Tehnik analisis data menggunakan uji prasarat (uji normalitas dan uji homogenitas) dan uji hipotesis.

\section{Hasil dan Pembahasan}

Hasil belajar siswa sebelum diberi perlakuan dapat diketahui total nilai pretest sebesar 1466 , rata-rata 63,739 , nilai tertinggi 87 dan nilai terendah 30 . Sedangkan nilai posttest setelah diberi perlakuan berupa penerapan model pembelajaran Number Head Together (NHT) mempunyai total nilai 1819 , ratarata 79,086 , nilai tertinggi 97 , dan nilai terendah 50 . Berikut diagram perbedaan hasil belajar siswa sebelum diberi perlakuan dan setelah diberi perlakuan berupa penerapan model pembelajaran Number Head Together (NHT).

\section{Diagram 1 Perbedaan Rata-rata Hasil} Pretest dan Posttest

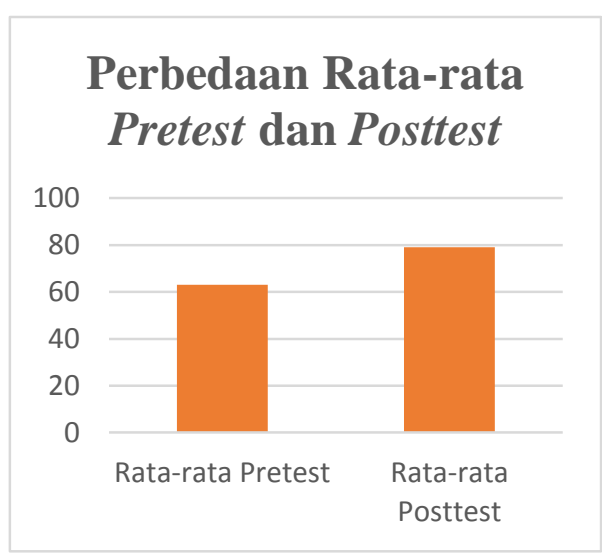

Berdasarkan diagram 1 di atas adanya perbedaan yang signifikan menunjukkan bahwa model pembelajaran Number Head Together (NHT) mempunyai pengaruh terhadap hasil belajar siswa. Nilai pretest mempunyai total nilai 1466 , rata-rata sebesar 63,739. Sedangkan nilai posttest mempunyai total nilai 1819 , ratarata sebesar 79,086 . Sehingga terdapat perbedaan antara hasil nilai pretest dan posttest, yaitu nilai posttest lebih tinggi dibandingkan nilai pretest. Adapun

85 | Pengaruh Model Pembelajaran Number Head Together (NHT) 
untuk menganalisis data menggunakan uji normalitas, uji homogenitas, dan uji hipotesis.

1. Uji Normalitas

Uji normalitas dilakukan untuk menentukan apakah data yang diperoleh berdistribusi normal atau tidak 25.0.

Tabel 1 Uji Normalitas

\begin{tabular}{|c|c|c|c|c|c|c|c|}
\hline \multicolumn{8}{|c|}{ Tests of Normality } \\
\hline \multirow{2}{*}{\multicolumn{2}{|c|}{ KELAS }} & \multicolumn{3}{|c|}{ Kolmogorov-Smirnov } & \multicolumn{3}{|c|}{ Shapiro-Wilk } \\
\hline & & Statistic & $D f$ & Sig. & Statistic & $D f$ & Sig. \\
\hline \multirow[t]{2}{*}{ Hasil Belajar Siswa } & Pretest & .170 & 23 & .083 & .933 & 23 & .124 \\
\hline & Posttest & .120 & 23 & $.200^{\circ}$ & 933 & 23 & .125 \\
\hline
\end{tabular}

Berdasarkan Tabel 1 di atas siswa berdistribusi normal karena dapat diketahui nilai signifikasi (sig.) dalam diperoleh signifikansi sebesar 0,125> penelitian ini menggunakan Shapiro-Wilk 0,05.

karena jumlah sampel $<50$. Nilai signifikansi uji Shapiro-Wilk nilai pretest signifikansi sebesar 0,124 >0,05. Jadi dapat disimpulkan bahwa data hasil belajar siswa berdistribusi normal karena diperoleh signifikansi sebesar 0,124 > 0,05 . Sedangkan nilai signifikansi uji Shapiro-Wilk nilai posttest signifikansi sebesar $0,125>0,05$. Jadi dapat tes

2. Uji Homogenitas

Uji homogenitas dilakukan setelah data persyaratan normalitas terpenuhi, yakni data dinyatakan berdistribusi normal. Kriteria pengujian apabila nilai signifikansi tes $>0,05$ maka tes tersebut homogen (sama), begitupun sebaliknya apabila nilai signifikansi tes $<0,05$ maka tidak homogen.
Tabel 2 Uji Homogenitas

\begin{tabular}{|l|l|l|l|l|l|}
\hline \multicolumn{7}{|c|}{ Test of Homogeneity of Variance } \\
\hline \multicolumn{2}{|c|}{} & $\begin{array}{l}\text { Levene } \\
\text { Statistic }\end{array}$ & $d f 1$ & $d f 2$ & Sig. \\
\hline Hasil Belajar Siswa & Based on Mean &, 015 & 1 & 44 &, 902 \\
\cline { 2 - 7 } & Based on Median &, 019 & 1 & 44 &, 891 \\
\hline
\end{tabular}

86 | Autentik: Jurnal Pengembangan Pendidikan Dasar, Vol. 4, No. 2, Tahun 2020 


\begin{tabular}{|l|l|l|l|l|}
$\begin{array}{l}\text { Based on Median and with } \\
\text { adjusted df }\end{array}$ &, 019 & 1 & 42,230 &, 891 \\
\hline Based on trimmed mean &, 002 & 1 & 44 &, 967 \\
\hline
\end{tabular}

Berdasarkan Tabel 2 diketahui data pada kelas pretest dan posttest homogen (sama). Data dapat dikatakan homogen apabila nilai signifikasi Based on Mean sebesar 0,902 > 0,05. Maka didapatkan bahwa hasil pretest dan posttest dan hasil belajar siswa mempunyai sig $=0,902$, maka dapat dinyatakan bahwa data pretest dan posttest hasil belajar siswa adalah homogen (sama).

3. Pengujian Hipotesis
Pengujian hipotesis bertujuan untuk memberikan jawaban apakah dapat diterima atau ditolaknya hipotesis yang diajukan dalam penelitian. Uji hipotesis yang digunakan dalam penelitian ini adalah uji paired samples $t$ test. Ketentuannya adalah jika nilai sig. (2-tailed) $\leq 0,05$, maka $\mathrm{H}_{\mathrm{a}}$ diterima dan $\mathrm{H}_{0}$ ditolak. Sebaliknya, jika nilai sig. (2tailed) $\geq 0,05$ maka $\mathrm{H}_{\mathrm{a}}$ ditolak dan $\mathrm{H}_{0}$ diterima. Berikut hasil perhitungan uji paired sample $t$ test.

Tabel 3 Uji Paired Samples T Test

\begin{tabular}{|c|c|c|c|c|c|c|c|c|c|}
\hline & \multicolumn{5}{|c|}{ Paired Differences } & \multirow[b]{3}{*}{$T$} & \multirow[b]{3}{*}{$D f$} & \multirow{3}{*}{$\begin{array}{l}\text { Sig. } \\
(2- \\
\text { tailed) }\end{array}$} \\
\hline & & \multirow[b]{2}{*}{ Mean } & \multirow{2}{*}{$\begin{array}{l}\text { Std. } \\
\text { Deviation }\end{array}$} & \multirow{2}{*}{$\begin{array}{l}\text { Std. } \\
\text { Error } \\
\text { Mean }\end{array}$} & $\begin{array}{l}95 \% \\
\text { Interval } \\
\text { Difference }\end{array}$ & $\begin{array}{l}\text { Confidence } \\
\text { of the }\end{array}$ & & & \\
\hline & & & & & Lower & Upper & & & \\
\hline $\begin{array}{l}\text { Pair } \\
1\end{array}$ & $\begin{array}{l}\text { Posttest - } \\
\text { Pretest }\end{array}$ & 15.34783 & 4.65743 & .97114 & 13.33380 & 17.36185 & 15.804 & 22 & .000 \\
\hline
\end{tabular}

Berdasarkan Tabel 3 di atas hasil terhadap hasil belajar pada uji paired sample $t$ test diperoleh nilai pembelajaran tematik.

sig. (2-tailed) posttest-pretest sebesar 0,000 . Sesuai dalam uji paired sample $t$ test bahwa nilai sig.(2-tailed) $\leq 0,05$ dalam hal ini $0,000 \leq 0,05$. Maka maka $\mathrm{H}_{\mathrm{a}}$ diterima dan $\mathrm{H}_{0}$ ditolak. Artinya terdapat pengaruh model pembelajaran Numbered Head Together (NHT) perlakuan yang berbeda dalam
Hasil belajar siswa diperoleh melalui pretest untuk mengetahui kemampuan awal siswa sebelum mendapatkan perlakuan. Sedangkan posttest untuk mengetahui kemampuan akhir siswa setelah mendapatkan perlakuan yang berbeda dalam 
penyampaian materi. Berdasarkan data hasil penelitian yang sudah dilakukan pada siswa kelas IVB dengan hasil pretest yang diperoleh rata-rata sebesar 63,739 sedangkan hasil posttest yang diperoleh rata-rata sebesar 79,086. Maka terdapat perbedaan antara hasil nilai pretest dan posttest, yaitu nilai posttest lebih tinggi dibandingkan nilai pretest. Berdasarkan hasil uji hipotesis (Uji-t) yang sudah dilakukan $\mathrm{H}_{\mathrm{a}}$ diterima dan $\mathrm{H}_{0}$ ditolak. Artinya terdapat pengaruh model pembelajaran Numbered Head Together (NHT) terhadap hasil belajar pada pembelajaran tematik.

Dengan demikian, adanya perlakuan model pembelajaran Numbered Head Together (NHT) siswa akan lebih tertarik dalam proses pembelajaran dimana siswa akan mendapatkan informasi dari kelompoknya untuk menuntaskan permasalahan yang tidak dipahami sebelumnya oleh siswa, menumbuhkan sikap mandiri, siswa menjadi lebih aktif berdiskusi, meningkatkan kerja sama siswa dalam kegiatan berdiskusi dan mampu membuat siswa bersemangat untuk melakukan pembelajaran tematik. Hal ini sejalan pendapat Palengka (2018:71) menyatakan bahwa model pembelajaran Numbered Head Together (NHT) merupakan sebagai salah satu pembelajaran yang menekankan pada struktur khusus yang dirancang untuk mempengaruhi pola interaksi siswa dalam kegiatan diskusi kelompok. Hal ini senada dengan pernyataan Sulfiani (2016:11) mengutarakan bahwa fungsi model pembelajaran Number Head Together (NHT) adalah siswa menjadi lebih aktif dalam proses pembelajaran dan minat siswa yang besar dalam kegiatan pembelajaran akan berpengaruh kepada peningkatan motivasi belajar siswa dan pada akhirnya akan berpengaruh pula terhadap hasil belajar siswa.

Penelitian yang dilakukan oleh Aprila Pegi Sasmita (2019) yang mendukung hasil penelitian ini, karena dalam penelitiannya dapat meningkatkan hasil belajar siswa pada mata pelajaran Matematika. Penelitian yang senada dilakukan Ita Susanti (2015) yang menunjukkan bahwa model pembelajaran Number Head Together (NHT) berpengaruh terhadap hasil belajar matematika siswa kelas VIII di MTs Muhammadiyah 2 Palembang. Adapun penelitian di atas berfungsi sebagai acuan atau referensi dalam melakukan penelitian ini. 


\section{Kesimpulan}

Berdasarkan hasil penelitian yang

telah dilakukan, dapat disimpulkan bahwa model pembelajaran Number Head Together (NHT) berpengaruh terhadap hasil belajar pada pembelajaran tematik. Hal tersebut dapat diketahui dari nilai rata-rata hasil pretest sebesar 63,739 sedangkan nilai rata-rata hasil posttest sebesar 79,086. Artinya terdapat peningkatan signifikan terhadap hasil belajar siswa setelah diberi perlakuan dengan penerapan model pembelajaran Number Head Together (NHT) sebesar 15, 347.

Berdasarkan simpulan di atas, adapun sarannya sebagai berikut yaitu bagi sekolah, diharapkan menjadi masukan bagi pihak sekolah dalam meningkatkan mutu pendidikan di Together(NHT). sekolah sebagai bahan evalusi untuk meningkatkan kompetensi guru dalam proses pembelajaran. Bagi guru, diharapkan dapat digunakan sebagai motivasi untuk memilih model pembelajaran yang lebih efektif dan bervariasi untuk mencapai tujuan pembelajaran dan membuat peserta didik aktif dalam proses pembelajaran. Bagi siswa, diharapkan peserta didik lebih berperan aktif dalam kegiatan pembelajaran dan percaya diri dalam menyampaikan pendapatnya. Sedangkan bagi peneliti, hasil penelitian ini diharapkan dapat memberikan masukan untuk melakukan penelitian selanjutnya dan dapat menambah pengetahuan dalam menggunakan model pembelajaran Number Head

\section{DAFTAR PUSTAKA}

Fujiawati, F. S. 2016. Pemahaman Konsep Kurikulum Dan Pembelajaran Dengan Peta Konsep Bagi Mahasiswa Pendidikan Seni. Jurnal Pendidikan dan Kajian Seni. Volume 1 Nomor 1 (April 2016): hlm 16-28, diakses 22 September 2019. http://jurnal.untirta.ac.id/index.php/JPKS/article/view/849

Sani, R. A. 2016. Penilain Autentik. Jakarta: PT Bumi Aksara.

Santosa, A .B., Damayanti, A. \& Dewi, S. U. 2016. Persepsi Model Pembelajaran Kooperatif Dan Motivasi Berprestasi Terhadap Hasil Belajar Mata Kuliah Bahasa Inggris. Jurnal Dewantara. Volume 2 Nomor 2 (September 2016): hlm 148-164, diakses $17 \quad 2020$. Journal.stkippgritrenggaek.ic.id/index.php/kid/article/view/84

Jayanti, G. A. M.E., Ardana, I. K. \& Putra, M. 2014. Penerapan Model Pembelajaran Kooperatif Tipe NHT Terhadap Hasil Belajar IPA Siswa Kelas V Sekolah

89 | Pengaruh Model Pembelajaran Number Head Together (NHT) 
Dasar Gugus Lt.Wisnu Depasar Utara. Jurnal Mimbar PGSD Universitas Pendidikan Ganesha. Volume 2 Nomor 1: hlm 1-11, diakses 02 Desember 2019.http://ejournal.undiksha.ac.id/index.php/JJPGSD/article/download/2554/2 $179 . \% 20 \% 5 \mathrm{~B} 11$

Yanti, K. D., Parmiti, D. P., \& Suwatra, I. I. W. 2016. Pengaruh Model Pembelajaran Kooperatif Tipe Numbered Head Together (Nht) Terhadap Hasil Belajar Ipa. Journal PGSD Universitas Pendidikan Ganesha. Volume 4 Nomor 1: hlm 1-10, diakses $20 \quad$ Maret 2020. https://ejournal.undiksha.ac.id/index.php/JJPGSD/article/viewFile/7445/5076)

Suandewi, N. K. \& Wibawa, I. M.C. 2017. Penerapan Model Pembelajaran Numbered Head Together Meningkatkan Hasil Belajar IPASiswa Kelas IV SD No. 3 Kapal. Jurnal IImiah Sekolah Dasar. Volume 1 Nomor 1: hlm 59-66, diakses 09 April 2020. undiksha.ac.id/index.php/JISD/article/download/10116/6456

Arikunto, S. 2013. Prosedur Penelitian Suatu Pendekatan Praktik. Jakarta: Rineka Cipta.

Sugiyono. 2017. Metode Penelitian Kuantitatif. Yogyakarta: Alfabeta.

Palengka,I. 2018. Perbedaan Hasil Belajar Matematika Siswa Kooperatif Tipe Number Head Togethe, Think Pair Share, dan Student Team Achievement Division Pada Kelas VIII SMP Kristen Kandora. Jurnal KIP. Volume 7 Nomor 3 (Februari 2019): hlm 69-73, diakses 06 Juni 2020. http://journals.ukitoraja.ac.id/index.php/jkip/issue/view/77

Sulfiani, R. 2016. Penerapan Model Pembelajaran Kooperatif Tipe Numbered Head Together (NHT) Untuk Meningkatkan Hasil Belajar Kimia Siswa Kelas XI IPA1 SMA Negeri 3 Watampone (Studi pada Materi Pokok Struktur Atom, Sistem Periodik Unsur dan Bentuk Molekul). Jurnal Chemica. Volume 17 Nomor 1 (Juni 2016): hlm 1-13, diakses 12 Maret 2020. http://ojs.unm.ac.id/chemica/article/download/4564/2613

Sasmita, A. P. Pengaruh Model Pembelajaran NHT (Numbered Head Together) Terhadap Hasil Belajar Siswa Pada Mata Pelajaran Matematika Di Kelas V SD Negeri 101882 Pasar VIII Desa Buntu Bedimbar Kecamatan Tanjung Morawa. Skripsi tidak diterbitkan. Medan. Fakultas IImu Tarbiyah Dan Keguruan Universitas Islam Negeri Sumatera Utara.

Susanti, I. Pengaruh Model Pembelajaran Kooperatif Tipe Number Head Together (NHT) Terhadap Hasil Belajar Matematika Siswa Kelas VIII Di MTs Muhammadiyah 2 Palembang. Skripsi Tidak Diterbitkan. Palembang. Fakultas Tarbiyah Dan Keguruan Universitas Islam Negeri Raden Fatah Palembang. 